\title{
10. Information systems teaching and research in West Australian universities
}

\author{
Janice Burn \\ School of Management Information Systems \\ Edith Cowan University \\ Craig Standing \\ School of Management Information Systems \\ Edith Cowan University \\ Chad Lin \\ Division of Health Sciences \\ Curtin University of Technology
}

\begin{abstract}
The authors of this chapter examine the current state of the development of information systems (IS) teaching and research within Western Australia (WA). A brief overview of the WA environment is followed by an exploration of teaching and research in the four main universities. This is examined against the framework for the study and, in particular, the impact of social processes (Ariav et al. 1987; Klein et al. 1991) and local contingencies (Culnan et al. 1993; Checkland and Holwell 1998), which are found to be of relevance to historical developments.
\end{abstract}

\section{The West Australian scene}

Western Australia is the largest state in Australia, spanning $2400 \mathrm{~km}$ from north to south and encompassing more than 2.5 million square kilometres. The state is fairly isolated from the rest of Australia and still maintains something of a 'frontier' mentality. This is compounded by the low population, with only two million inhabitants, approximately 73 per cent of whom live in the capital city of Perth, which has a current population of 1.5 million. The rest of Western Australia is populated by small country towns, which are typically remote from other centres and many of which lack basic infrastructure such as health and education services. In particular, broadband access is variable and information and communication technology (ICT) services can be poor. 


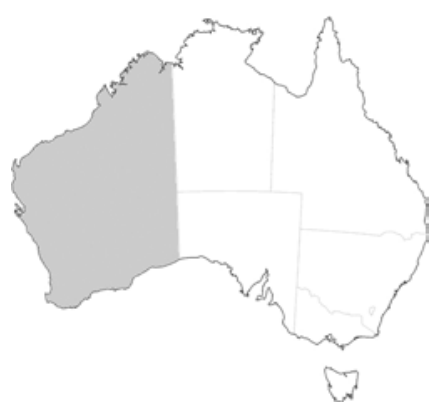

Figure 10.1 Location of Western Australia within Australia

The capital city of Perth has the dubious reputation of being the most remote city in the world, being as close to Singapore as it is to Sydney and a five-hour flight from either. This has compensations since Perth is on the same time zone as the Asian centres of Hong Kong and Singapore and hence is attractive for international collaboration in business and, indeed, in education. The remoteness of the state has, however, meant that few businesses headquarter in Western Australia and, as such, collaboration with local industry becomes a problem since they tend to favour states where they are headquartered. The state also derives most of its revenue from the minerals and oil industries, with the majority of large companies associated with mining in some form.

These location factors have impacted on the development of WA universities, since, while all four public universities are based in Perth, they all have a remit to service the whole state and so typically have remote campuses across Western Australia. Additionally, all universities have substantial external offerings, which initially targeted the distant WA population but now recruit from a global community. The WA population has remained fairly stable but is now forecast to grow; however, the growth in university students has come largely from out-of-state enrolments and, specifically, from Asia.

\section{Overview of WA universities}

The five universities in Western Australia (ordered by number of enrolments from largest) are:

- Curtin University of Technology

- Edith Cowan University (ECU)

- the University of Western Australia (UWA)

- Murdoch University

- Notre Dame University. 
Table 10.1 Overall enrolment figures for 2004 and comparative statistics

\begin{tabular}{l|c|c|c|c|c}
\hline University & Total & \% overseas & \% postgraduate & \% research & $\begin{array}{c}\% \\
\text { school-leavers }\end{array}$ \\
\hline Curtin & 36064 & 39.7 & 22.2 & 4.3 & 43.1 \\
\hline ECU & 23887 & 17.8 & 19.6 & 2.6 & 33.1 \\
\hline UWA & 16806 & 17.7 & 25.8 & 11.3 & 75.0 \\
\hline Murdoch & 12655 & 17.5 & 17.8 & 6.5 & 34.9 \\
\hline Notre Dame & $3000+$ & N/A & N/A & N/A & N/A $^{a}$ \\
\hline
\end{tabular}

${ }^{a}$ Notre Dame University is a private Catholic university

Source: Department of Education, Science and Training Selected Higher Education Statistics.

A brief historical overview of these five universities helps to explain the particular unique focus of each institution and the positioning of IS within the universities.

\section{University of Western Australia}

The UWA was the state's first university, established in 1911, and is a member of the Group of Eight - the eight most prominent research-oriented universities in Australia, often referred to as the 'Sandstone universities'. The UWA has proportionately the highest intake of school-leavers nationally (national average, 44.3 per cent) and consistently recruits more than 80 per cent of the state's top 5 per cent of school-leavers. The Good Universities Guide says that the 'UWA has more young, bright full-timers than any other University in the country-it is at the top of the WA academic totem pole'. Typically, all undergraduate students are full-time. With this profile of students, the most popular disciplines are the traditional ones and IS plays only a supporting role. Originally, IS was part of the Department of Information Management and Marketing (DIMM), founded in 1993. A full major of IS units was first offered in 1998. The information management (IM) discipline group is now embedded within the School of Economics and Commerce - itself one of two schools in the UWA Business School.

\section{Curtin University of Technology}

Curtin University of Technology is Western Australia's largest university and evolved from the Western Australian Institute of Technology (WAIT) in 1986. The WAIT was itself created in 1966 from the Perth Technical College, which in 1969 merged with the WA School of Mines, the Muresk Agricultural College and the Schools of Physiotherapy and Occupational Therapy. Between 1966 and 1976, student enrolments expanded from 2000 to more than 10000 and the WAIT consolidated around three large schools of Health Sciences, Business and Administration and Arts and Architecture.

The WAIT's Business School was the largest in Australia and, in 1975, the School of Computing and Quantitative Studies was formed, with a prime focus on IS. In 1986, when Curtin University was formed, the school was renamed the School 
of Information Systems and remains within the Business Faculty. There is a separate School of Computer Science in a different faculty.

Curtin has a main campus and two additional metropolitan campuses in Perth, as well as regional campuses in Kalgoorlie and Northam. In addition, it has an offshore campus in Sarawak, Malaysia, and a new campus in Sydney's central business district. Curtin has 13 education centres within Western Australia and 15 overseas education centres.

Curtin has the largest international student population in the state, with about 40 per cent - which is high by national standards. These students will typically be full-time and their Australian counterparts a mix of full-time and part-time.

\section{Edith Cowan University}

Edith Cowan University (ECU) was granted university status in 1991 and evolved from a number of education colleges formed as early as 1902. ECU remains the state's major provider of teacher education. While it is the state's second-largest university, it has the largest enrolment of WA students. ECU focuses on the service professions and defines its particular strengths as:

- education

- $\quad$ nursing

- business

- computing

- communications

- creative and performing arts.

Information systems was part of the School of Information Systems and Management Science in the 1980s and became the Department of Management Information Systems in 1988 within the Faculty of Business. A separate School of Computer Science is in a different faculty.

ECU had many campuses but has recently consolidated and now has its main campus $28 \mathrm{~km}$ north of the city centre in Joondalup - one of the fastest growth areas in Australia. It has a second city campus and a regional campus at Bunbury in the south.

More than 50 per cent of the students at ECU are 'mature' entrants and are typically part-time students. With this profile, IS students would normally come from within the IT industry. As IT suffered a decline in 2004 and 2005, so the student population declined in this period.

\section{Murdoch University}

Murdoch University was formally constituted as Western Australia's second university in 1973 and, while a research-based university, it has a strong emphasis on good teaching. Information systems has had a chequered history 
as part of an IT group. Originally, the Department of Information Technology was part of the School of Mathematics, Business and Sciences, but, in 1997, IT was moved to Business Information Technology and Law. In 2003, the School of Information Technology was moved into the Division of Arts.

Murdoch University has three campuses - two regional campuses and one city campus.

\section{Notre Dame University}

The University of Notre Dame was founded in 1990 and is a private Catholic university. Despite its small size, it has eight colleges and the School of Information Technology resides within the College of Science and Technology. Interestingly, all the courses offered in IT are offered in online mode and the university spawned a separate company to promote the development of such online material. There is no IS group as such and the IT school has only two permanent staff members.

For the purposes of this study, only the public universities are considered in depth. Notre Dame does not have an IS department.

Table 10.2 An overview of the approximate numbers of IS staff and student numbers within the four public universities.

\begin{tabular}{l|c|c|c|c}
\hline University & Unit & IS staff & $\begin{array}{c}\text { IS undergraduate } \\
\text { students }\end{array}$ & $\begin{array}{c}\text { IS postgraduate } \\
\text { students }\end{array}$ \\
\hline Curtin & School of IS & 24 & $\sim 160$ & $\sim 200$ \\
\hline ECU & School of MIS & 18 & $\sim 150$ & $\sim 110$ \\
\hline UWA & School of IT & 7 & $\sim 100$ & $\sim 25$ \\
\hline Murdoch & School E and C & 8 & $\sim 70$ & $\sim 10$ \\
\hline
\end{tabular}

Within these staffing numbers, Curtin University has three IS professors, Edith Cowan has three IS professors and the UWA and Murdoch have no IS professors.

\section{The study}

Interviews were conducted with senior academics at the four public universities. The data summarised below represent the picture at that time. It should be noted, however, that in all cases, numbers were falling at the time of the interviews, with a severe decline in student enrolments and commensurate reduction in staff numbers. The dramatic upswings and down-swings in student numbers in the IS discipline over the years suggest that the 'discipline' is aligned very tightly with the perceived industry needs of the moment rather than being viewed as a substantive 'professionalised' academic discipline in its own right (Ruscio 1987).

\section{Courses}

Curtin University covers the whole spectrum of IT, electronic commerce (EC) and IS, with a recent emphasis towards some of the more technical IS subjects; 
ECU focuses on the business applications of IS, EC and IM with a specialisation in enterprise resource planning (ERP) at postgraduate level; the UWA clearly identifies IM as its specialisation, with a focus on support for other discipline majors such as accounting and marketing; and Murdoch focuses on the more technical aspects of IS such as IS development and the use of multimedia. ECU is also targeting a new market, with a Masters Degree in Strategic Project Management, which it hopes will appeal to a broader market base.

Table 10.3 The wide variety of courses offered across all four universities.

\begin{tabular}{l|l|l}
\hline University & Undergraduate courses & Postgraduate courses \\
\hline Curtin & Bachelor of Commerce (IS) & Grad Dip/Certificates \\
& Bachelor of Commerce (IT) & Postgrad Dip/Certificates \\
& Bachelor of Commerce (EC) & Master (IS) \\
& & PhD \\
\hline ECU & Bachelor of Business (IS) & Grad Dip/Certificates (IS, EC, ERP) \\
& Bachelor of Business (EC) & Master (IS) \\
& Bachelor of Business (IM) & Master Strategic Project Management \\
& Bachelor of IS & DBA (IS) \\
& & PhD \\
\hline UWA & Bachelor of Commerce (IS) & Master of Information Management \\
& & Master of Commerce (IM) \\
& PhD \\
\hline Murdoch & Bachelor of Science (IS Dev) & Grad Dip \\
& Bachelor of Science (BIS) & Masters IS \\
& Bachelor Science (Multimedia) & PhD \\
& Bachelor of Science in IS & \\
\hline
\end{tabular}

Despite some low enrolments in the undergraduate and postgraduate programs, $\mathrm{PhD}$ programs continue to thrive in all four IS groups, with a total of about 60 doctoral students by research. In addition, ECU offers a unique DBA program in IS. This is a partially taught program with a shorter thesis component and has a further 20 doctoral students, drawn mainly from senior managers in the WA community. In general, enrolments in general degrees such as the Bachelor of Business with IS specialisations remain fairly steady, but enrolments in specialist IS degrees are dropping radically. Interest in multimedia has declined significantly and electronic commerce no longer holds the appeal it once did. There has been a substantial decline in international recruitment, impacting on the postgraduate market.

\section{Research}

Research focus within the four universities also varies widely and this could be one of the reasons why all interviewees identified a low level of collaboration between WA universities. Indeed, at the time of writing, there were no joint projects and staff in each university seemed unfamiliar with research being conducted in other WA institutions. Funding was variable, with the onus on staff to generate funding through successful grant applications, internally or 
externally, or through collaborative partnerships with industry. Curtin has an industry-sponsored professor, which comes with considerable prestige in addition to research funds.

Research output also varied considerably. At the UWA, the research activity of staff was largely interdisciplinary and had a relatively low proportion contributing to strictly IS-related research, compared with a high output overall at ECU, with about 90 per cent of staff research active. Curtin followed the more typical path, with 20 per cent of staff providing 80 per cent of output. It was stated that Curtin had shifted emphasis towards teaching over research in recent years, but this could be changing as Curtin has made a strategic move to be a research-intensive university. Identified themes for continuing research are shown in Table 10.4.

\section{Table 10.4 Research themes}

\begin{tabular}{|c|c|c|c|}
\hline University & Themes & Groups & Funding \\
\hline Curtin & $\begin{array}{l}\text { Technology adoption } \\
\text { Information technology } \\
\text { Management } \\
\text { Health informatics } \\
\text { Relational ontology } \\
\text { World-wide databases } \\
\text { Grid supercomputing } \\
\text { Electronic commerce } \\
\text { Soft-systems methodology }\end{array}$ & $\begin{array}{l}\text { Individuals }+ \text { PhD groupings } \\
\text { around professors }\end{array}$ & $\begin{array}{l}\text { Grant-based + Research } \\
\text { Performance Index funding } \\
\text { system }\end{array}$ \\
\hline$\overline{E C U}$ & $\begin{array}{l}\text { Electronic markets } \\
\text { Collaborative commerce in } \\
\text { small and medium-sized } \\
\text { enterprises (SMEs) } \\
\text { IS evaluation } \\
\text { IS in the construction industry } \\
\text { IS education and IS in } \\
\text { education }\end{array}$ & $\begin{array}{l}\text { Five formal research groups } \\
\text { led by the professors/associate } \\
\text { professors } \\
+ \text { individual } \\
\end{array}$ & $\begin{array}{l}\text { Grant-based + Research } \\
\text { Activity Index funding system }\end{array}$ \\
\hline UWA & $\begin{array}{l}\text { Knowledge management } \\
\text { Virtual communities } \\
\text { E-government } \\
\text { Transport modelling } \\
\text { Compliance-monitoring } \\
\text { systems }\end{array}$ & \begin{tabular}{|l|} 
Individuals and \\
interdisciplinary and \\
inter-faculty collaborations
\end{tabular} & $\begin{array}{l}\text { Grant-based and individual } \\
\text { research support from school } \\
\text { funds }\end{array}$ \\
\hline Murdoch & $\begin{array}{l}\text { Human factors in IS } \\
\text { Knowledge management } \\
\text { E-learning } \\
\text { Decision support } \\
\text { Business strategy alignment }\end{array}$ & Individuals & $\begin{array}{l}\text { Grant-based + individual } \\
\text { allocation from school }\end{array}$ \\
\hline
\end{tabular}

Curtin and ECU operate a research performance-monitoring scheme, which is linked directly to research funding (Curtin University-Research Performance Index; ECU-Research Activity Index). In this way, staff members are rewarded with a dollar value applied to the number of points they have generated towards the research assessment quantum. This scheme provides considerable incentive for staff to become productive but can favour quantity over quality. At ECU, 
however, the recent trend has been to decrease the funding per point being allocated to staff and to the use the money to provide competitive internal research grants.

All four universities support qualitative and quantitative research and employ multiple methods. Case studies and interpretive research were commonly applied. The overall research picture in Western Australia fits closely with the view of a 'fragmented adhocracy' (Whitley 1984; Culnan et al. 1993; Checkland and Holwell 1998), with low researcher mutual dependency and very different contributions from each of the four universities, reflecting local political pressures from within their different institutions but also from within the state - where all four compete for highly limited funding.

\section{IS leadership}

The particular environment of Western Australia has strongly influenced IS leadership since West Australians are often loath to leave the state because of the rather laidback life-style and Mediterranean climate, with core academic staff remaining fairly static over the long term. In addition, Western Australia is seen as a desirable location for international immigrants and, hence, the state attracts a fair share of international academics. It is rare to see Australian academics from the eastern states choose to relocate to the west. This has had two consequences: WA academics have had to strive for excellence within the Australian arena; and Western Australia has gained an international profile through its international academics. Richard Watson (originally from Western Australia), Bob Galliers and Janice Burn have all contributed to the development of IS within the state, coming from an international perspective, and West Australians Graham Pervan and Bernie Glasson have had significant input nationally and internationally. All six current professors at Curtin and ECU are well-known researchers with national and international reputations.

Interviewees stressed the real need for IS leadership and active involvement in IS research by the professoriate. Information systems groups without a professor tended to have a significantly lower profile in their home university.

\section{Key academics in the development of IS in Western Australia}

\section{Richard Watson}

Richard Watson led the development of the School of Information Systems at the Western Australian College of Advanced Education in the 1980s before it was granted university status. During this period, he undertook a $\mathrm{PhD}$ in the United States and, after returning to Perth for a period, decided to relocate to Athens, Georgia, in 1989. He has retained links with universities in Western Australia and is a frequent visitor. He is currently J. Rex Fuqua Distinguished 
Chair for Internet Strategy in the Department of MIS at the University of Georgia's Terry College of Business.

\section{Graham Pervan}

Graham Pervan is Professor of Information Systems at Curtin University. He has been involved in the development of the discipline for more than 25 years, has been head of school and is currently President of the Australian Council of Professors and Heads of Information Systems (ACPHIS).

\section{Janice Burn}

Janice Burn has had a 30-year career in IS and was Foundation Professor and Head of School of Management Information Systems at Edith Cowan University from 1997 to 2005. She previously held senior academic posts in Hong Kong (Associate Professor and Associate Head of School, Hong Kong Polytechnic) and the United Kingdom (Principal Lecturer, Coventry Polytechnic). She was a member of the Australian Research Council (ARC) and an adviser to the Australian government on IT and national research priorities. Burn was instrumental in developing the School of Management Information Systems into a research-intensive school during her time at ECU. She was also highly innovative in leading course development, with many successful courses launched.

\section{Conclusions}

The main IS strength in Western Australia lies in Curtin and ECU, where separate IS schools have been in existence for more than 30 years. In 2007, the IS school at ECU merged with the School of Management to form a new school, but it still retains its identity as a discipline. Information systems is recognised as a discipline at the UWA and Murdoch, but as a subset of other disciplines, and it has a somewhat lower status in these two institutions. Different value systems and funding models inhibit collaboration between the four institutions. In 1998, Curtin took the lead to organise the WA workshop in IS research (WAWISR) and this was repeated each year, hosted by each university in turn until 2001, when enthusiasm to organise it was exhausted. Sadly, one of the reasons for this could be the increased emphasis on recognised research output, lessening the motivation for activities that would be regarded solely as community building. Similarly, in 1999, ECU ran the first Working for e-Business (WeB) conference based in Perth and continued to organise this until 2004. This conference attracted some local attendees but many more came from across Australia to forge national collaborative links.

With respect to the development of IS as a discipline, social processes and local contingencies seem to have had considerable impact. Western Australia is the most distant state in Australia and hence looks inward to local industry for direction, but also outwards from Australia to forge international reputations. 
Mechanisms of control are very much still in a developmental mode although this applies to the country as a whole, with IS representation on the national research funding body, the ARC, being achieved only in 2000 with the appointment of Professor Janice Burn as the IS discipline representative on the ARC research panel for Mathematics, Information and Computer Sciences. The core body of knowledge taught at each of the four universities tends to reflect local allegiances with industry, services and professions and varies in line with local developments and needs rather than necessarily responding directly to demands from within the discipline itself.

All interviewees commented on the decrease in numbers in IS and diminishing staff numbers, which suggests that the picture painted in this study could change significantly in the next few years. It was also interesting to note that IS was seen to be a discipline grouping that could be transposed easily from within one discipline grouping to another, with residual homes having been found in business, science, mathematics and even engineering at one time or another across the four institutions. From the WA perspective, it would appear that IS is still 'a perspective' (Fitzgerald 2003) rather than a discipline - and a perpetually shifting perspective at that.

\section{Acknowledgements}

Thanks are due to the following interviewees: Professor Janice Burn, ECU; Dr Nick Letch, the UWA; Professor Graham Pervan, Curtin; Professor Craig Standing, ECU; Dr Fay Sudweeks, Murdoch; and Danny Toohey, Murdoch.

\section{References}

Ariav, G., de Sanctis, G. and Moore, J. 1987, 'Competing reference disciplines for MIS research', Proceedings of the Eighth International Conference on Information Systems, Pittsburgh, pp. 455-8.

Checkland, P. and Holwell, S. 1998, Information, Systems and Information Systems - Making Sense of the Field, Wiley \& Sons, Chichester.

Culnan, M. J., Swanson, E. B. and Keller, M. T. 1993, 'MIS research in the 1980s: shifting points of work and reference', Proceedings of the 26th Hawaii International Conference on Systems Sciences, vol. 3, pp. 597-606.

Fitzgerald, G. 2003, 'Information systems: a subject with particular perspective, no more, no less', European Journal of Information Systems, vol. 12, no. 3, pp. 225-9.

Klein, H. K., Hirshheim, R. and Nissen, H. 1991, 'A pluralist perspective of the information systems research arena', in H. E. Nissen, H. K. Klein and R. Hirshheim (eds), Information Systems Research: Contemporary Approaches and Emergent Traditions, Elsevier, Amsterdam. 
Ruscio, K. 1987, 'Many sectors, many professionals', in B. Clarke (ed.), The Academic Profession, University of California Press.

Whitley, R. 1984, 'The development of management studies as a fragmented adhocracy', Social Science Information, vol. 23, no. 4-5, pp. 775-818. 